\title{
Mangifera indica and Mangifera zeylanica: Perspectives on medicinal properties, therapeutic applications and potential uses as anticancer epigenetic drugs (Review)
}

\author{
ILAKYA SELVAKUMAR $^{1 *}$, ASHWINI VASUDEVAN $^{1 *}$, NIRMAL PERERA $^{2 *}$, MERAN KESHAWA EDIRIWEERA $^{3}$, \\ DEVIPRIYA NAGARAJAN ${ }^{1}$, SAMEERA RANGANATH SAMARAKOON ${ }^{2}$, \\ KAMANI HEMAMALA TENNEKOON $^{2}$ and VADIVEL VELLINGIRI ${ }^{1}$ \\ ${ }^{1}$ School of Chemical and Biotechnology, SASTRA Deemed University, Thanjavur, Tamil Nadu 613401, India; \\ ${ }^{2}$ Institute of Biochemistry, Molecular Biology and Biotechnology, University of Colombo, Colombo 00300; \\ ${ }^{3}$ Department of Biochemistry and Molecular Biology, Faculty of Medicine, University of Colombo, Colombo 00800, Sri Lanka
}

Received December 22, 2021; Accepted February 1, 2022

DOI: $10.3892 /$ ije. 2022.10

\begin{abstract}
Among the different types of mango species, Mangifera indica (MI) and Mangifera zeylanica (MZ) are well known for their therapeutic potential. MI is a pharmacologically and phytochemically diverse plant. Extracts prepared from different parts (bark, leaves, roots, seeds, flowers and fruits) of MI and major mango phytochemicals have been reported to exert a range of pharmacological effects. $\mathrm{MZ}$ is a plant endemic to Sri Lanka. The bark of MZ has been used in the Sri Lankan traditional medicine for the treatment of various ailments and conditions, including cancer. Recently, substantial efforts have been made to provide a scientific validation for its traditional use in the treatment of cancer. The present review article describes the pharmacological activities, including anti-inflammatory, antioxidant, anticancer, anti-microbial, anti-diabetic and anti-obesity properties of MI. Furthermore, the anticancer potential of MZ bark extracts and information on compounds isolated from $\mathrm{MZ}$ and their bio-activities are also described. The effects of major Mangifera compounds on epigenetic modifications have been widely studied. Therefore, the ability of Mangifera compounds to function as epigenetic drugs in the context of cancer drug discovery has become a
\end{abstract}

Correspondence to: Dr Sameera Ranganath Samarakoon, Institute of Biochemistry, Molecular Biology and Biotechnology, University of Colombo, 90 Cumarathunga Munidawa Mawawtha, Colombo 00300, Sri Lanka

E-mail:sam@ibmbb.cmb.ac.lk

Dr Devipriya Nagarajan, School of Chemical and Biotechnology, SASTRA Deemed University, Thanjavur, Tamil Nadu 613401, India E-mail: radiationbiologyscbt@gmail.com

*Contributed equally

Key words: Mangifera indica, Mangifera zeylanica, epigenetics, mango phytochemicals, cancer promising area of investigation. However, an assessment of the clinical efficacy, and potential adverse and toxic effects of mango extracts is essential prior to their use in clinical practice.

\section{Contents}

1. Introduction

2. Medicinal properties of MI

3. Medicinal properties of $\mathrm{MZ}$

4. Epigenetic modifications in human cancer

5. Phytochemicals common to both $\mathrm{MI}$ and $\mathrm{MZ}$

6. Conclusion

\section{Introduction}

Mango is a fruit-bearing tree cultivated in tropical and sub-tropical regions of the world, with India being the largest producer (1). The genus Mangifera (family Anacardiaceae) comprises $>70$ species and 1,000 varieties (2). Among the various species, MI is the most widely found species across India, China, Mexico, Brazil, Pakistan, Thailand and The Philippines. MI is believed to have originated from the Indo-Burma region (2). The mango fruits are popular due to sensorial properties, such as a bright colour, luscious flavour and sweet taste (3). A large variety of phytochemicals with distinct chemical structures and a range of pharmacological properties have been reported in MI (1). Furthermore, various parts of MI have been used in the traditional medicines of South Asian and African countries. For example, extracts and decoctions prepared from different parts of MI are used in the treatment of various ailments and conditions, including anaemia, asthma, bronchitis, cough, diarrhoea, dysentery, haemorrhage, hypertension, leucorrhoea, piles and rheumatism, blisters and oral wounds, and animal bites (1). Images of Mangifera indica (MI) leaves, bark and fruits are presented in Fig. 1A (left panel, middle panel and right panel, respectively). 
Mangifera zeylanica (MZ), a species in the mango family, is a plant endemic to Sri Lanka. Similar to MI, MZ also bears edible fruits (4). The tree grows up to a height of $10-30 \mathrm{~m}$ and branches from a stout trunk. Compared with MI, MZ possesses smaller leaves $(7-13 \mathrm{~cm}$ in length, dark green and shiny) and fruits (3-5 cm long and ripen fruits are yellow in colour) (Fig. 1B). The seed occupies a larger volume of the fruit than the fruit pulp (4). In Sri Lankan traditional medicine, the bark of $\mathrm{MZ}$ has been used in the treatment of various ailments and diseases, including cancer (1). According to the International Union for Conservation of Nature (IUCN), MZ has been classified as a vulnerable species (5). MZ leaves, bark and fruits are presented in Fig. 1B (left panel, middle panel and right panel, respectively).

Epigenetics modifications arise due to alterations in gene function that cannot be endorsed to DNA sequence modifications. Two key biological processes, DNA methylation and histone modifications (histone acetylation, deacetylation sumoylation and ubiquitylation) have been reported to largely contribute to such epigenetics modifications (6). In normal cells, it has been reported that the functions of a number of genes are highly regulated through DNA methylation and histone modifications (6). Given that epigenetic modifications tightly control gene expression, it is not surprising that any irregularity in the epigenetic modification is associated with aberrant gene functions (7). Notably, the dysregulation of epigenetics modifications have been reported in a range of human cancers (8). Several phytochemicals have been identified as promising drug candidates which can re-establish aberrant epigenetic profiles (9). The present review article discusses the biological and pharmacological effects of various extracts and phytochemicals of MI and MZ, as well as the effects of major mango bio-active compounds on epigenetic modifications.

\section{Medicinal properties of MI}

MI is one of the widely used medicinal plants. A number of pre-clinical investigations have reported a range of pharmacological effects of different MI extracts (1). MI is well known to possess polyphenolic compounds, which have been found to have diverse biological activities (1). Different parts of MI, including the leaves, stem, flowers, fruits and seeds possess essential nutrients, such as vitamins and minerals (10). The following sections describe some experimentally validated pharmacological effects (antioxidant, anti-inflammatory, anti-diabetic, anti-obesity and anti-microbial properties) of different parts (leaves, bark, seed and fruit peel and flesh) of MI.

Antioxidant properties. A number of studies have demonstrated the antioxidant properties of extracts prepared from different parts of MI. Dhital (11) demonstrated that the leaf methanol extract of MI exerts moderate free radical scavenging effects (12). In another study, among the aqueous bark extracts prepared from the Keitt, Kent, Honey (originally Ataulfo) and Tommy Atkins MI varieties, the aqueous bark extract of Kent was reported to possess the most pronounced antioxidant properties. Moreover, the Ataulfo extract was found to exert the most prominent cellular anti-oxidant effects (12). The leaf methanol extract of Mahajanaka, a mango variety found in Thailand, has been shown to exert potent free radical scavenging effects. The same leaf extract has also been shown to inhibit lipopolysaccharide-induced nitric oxide production in RAW264.7 cells (13). In another study by John et al 2012, exposure to an aqueous ethanol extract of MI stem bark increased the red blood cell count in Wistar strain albino rats, indicating its ability to enhance erythropoiesis and exert protective effects against oxidative damage. Furthermore, the increment of monocytes and neutrophils following exposure to the aqueous ethanol extract indicated its ability to enhance and modulate immunological activities (14). The leaf ethanolic extract of MI has been found to have antioxidant properties in vivo. In a previous study, the attenuation of cerebral oxidative status in rats was observed when the rats were fed various different doses of MI leaf ethanol extract. Moreover, increased levels of malondialdehyde, and reduced superoxide dismutase and glutathione peroxidase activities were observed in the hippocampus of the tested animals (15). The ethanolic extract of MI fruits has also been found to exert protective effects against cognitive impairment and oxidative stress (16). These observations indicate the ability of the MI plant extract to function as antioxidant in vitro and in vivo.

Anti-inflammatory properties. The anti-inflammatory properties of mango peel, seed and pulp of Sri Lankan mango varieties have been investigated (17). Experiments conducted using the human red blood cell membrane stabilization assay demonstrated that the peel, pulp and seed ethyl acetate extracts of three different mango varieties (Willard, Vellaicolomban and Karthacolomban) exerted anti-inflammatory activities. Among these, the ethyl acetate extract of Karthacolomban seeds exhibited the highest anti-inflammatory activity (17). The ethanol leaf extract of MI was found to possess analgesic and anti-inflammatory effects in-vivo (18). Wistar Hannover rats treated with MI leaf ethanol extract have also been shown to exhibit diminished inflammatory activities induced by $4 \%$ formalin (19). In the study by Kim et al (20), polyphenolic derivatives of MI were shown to modulate dextran sulfate sodium (DSS)-induced colitis in rats, suggesting that MI polyphenolic derivatives can attenuate inflammatory responses. In another study, the methanol extract of MI stem bark was found to exert anti-inflammatory effects against DSS-induced colitis (21). Moreover, the administration of aqueous stem bark extracts of MI resulted in a reduction in the levels of thiobarbituric acid reactive substances, the expression of tumour necrosis factor- $\alpha$ (TNF- $\alpha$ ), cyclooxigenase- 2 , inducible nitric oxide synthase and TNF receptor- 2 in colonic tissue and, and in serum TNF- $\alpha$ and interleukin (IL)-6 levels (21). Collectively, these findings suggest that mango peel, seed and leaf extracts possess anti-inflammatory properties.

Anti-diabetic and anti-obesity effects. The study by Perpétuo and Salgado (22) demonstrated the effects of diets containing mango flour on blood glucose levels in diabetic rats. Diabetic rats fed mango flour exhibited reduced blood glucose levels from the 10th day of feeding. Moreover, a $64 \%$ reduction in glycogen levels was observed compared to the control group (22). MI flavonoids have been reported to reduce blood glucose levels in Swiss albino mice with induced diabetes (23). Furthermore, MI leaf aqueous extract was found to increase high-density lipoprotein levels (23). The ethanol (95\%) 
A
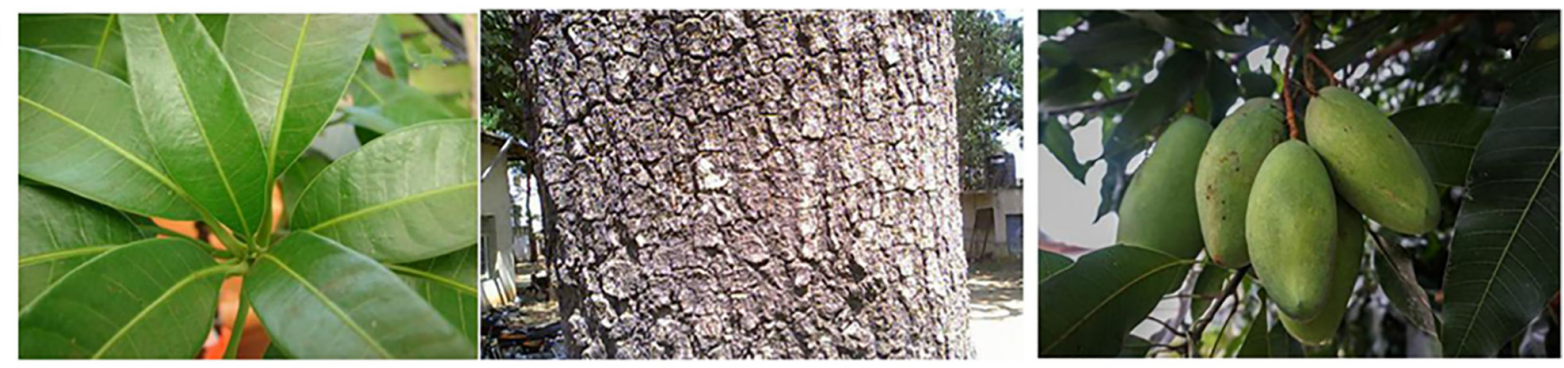

B
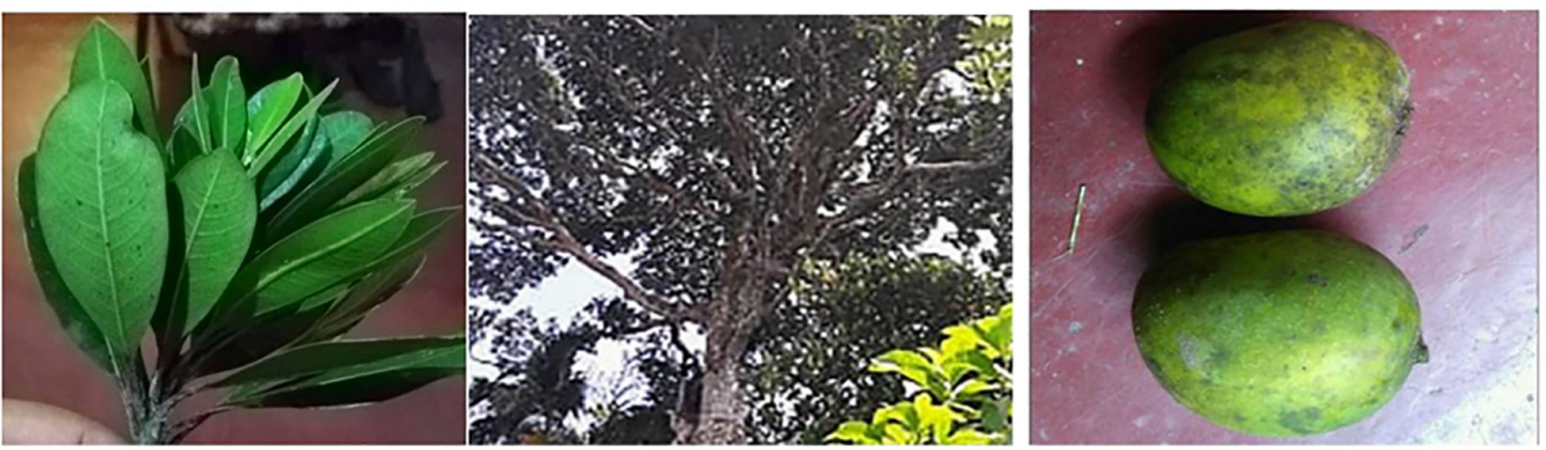

Figure 1. (A) Mangifera indica leaves (left panel), bark (middle pane) and fruits (right panel). (B) Mangifera zeylanica leaves (left panel), bark (middle pane) and fruits (right panel).

extract of MI leaves and mangiferin modulated the endocannabinoid (CB) system and peroxisome proliferator-activated receptor- $\gamma(P P A R \gamma)$ mRNA expression in cafeteria diet-fed rats, suggesting a possible role for MI in controlling obesity and metabolic syndrome (24). The endocannabinoid system has been reported to contribute to weight gain and glucose intolerance, while PPAR $\gamma$ is one the key regulators of adipose cell development and differentiation (24).

The peel acetone extract of MI possesses hypoglycaemic effects. The study by Gondi and Rao illustrated that the leaf extract of MI can be used against streptozotocin-induced diabetes in rats (25). Rats fed various doses of MI peel extracts were found to have lower levels of glycated haemoglobin (25). Narasimhan et al (26) also demonstrated that albino rats of the Wistar strain fed various doses of ferulic acid, a major compound found in mango, exhibited an enhanced glycogen synthesis, improved blood glucose tolerance and reduced gluconeogenic enzyme activities. Moreno et al (27) demonstrated that MI extracts inhibited the action of lipoprotein lipase and hormone sensitive lipase in male Wistar rats. Animals receiving stem bark and leaf extracts exhibited an inhibition of isoproterenol-stimulated glycerol release and an increment in faecal fat. Moreover, animals receiving MI leaf extract also exhibited an inhibition of pancreatic lipase (27). A study on lean and obese individuals identified that a mango supplementation decreased plasminogen activator inhibitor-1, glycated haemoglobin and inflammatory cytokine (IL-8 and monocyte chemoattractant protein-1) levels in obese individuals and controlled blood pressure, indicating a positive role of mango consumption against metabolic and obesity-related chronic diseases (28).

Anti-microbial properties. Acetone extracts of MI leaves have been shown to exhibit antibiotic activity against antibiotic-sensitive and multidrug-resistant bacteria, such as Salmonella typhi, Staphylococcus aureus and Salmonella typhimurium (29). Furthermore, a methanol extract of the seed kernal of MI has been found to exert inhibitory effects against Staphylococcus aureus, Escherichia coli and Bacillus subtilis (29). In the study by Manzur et al (30), aqueous and ethanolic extracts of MI leaves were found to exert inhibitory effects against Stapylococcus species isolated from cows. In another study, Mushore and Matuvhunye (31) demonstrated that an aqueous extract of stem bark of MI can reduce the growth of $S$. aureus. A recent study demonstrated that the hexane peel extract prepared from the Sindhura and Banisha mango varieties found in India exerted growth inhibitory effects against Escherichia coli (32). In addition, methanolic and ethyl acetate peel extracts was found to exert inhibitory effects against Bacillus subtilis and Pseudomonas aeruginosa, respectively (32). These findings suggest the potential use of MI extracts and by-products as anti-microbial agents. Further studies are required however, to elucidate anti-microbial mechanisms and to isolate active compounds.

Anticancer properties. Various extracts and compounds isolated from MI have been reported to exert anticancer effects in vitro and in vivo. Noratto et al (33) evaluated the anticancer effects of polyphenolic extracts prepared from five mango varieties (Haden, Francis, Honey, Kent and Tommy Atkins) in breast (MDA-MB-231), lung (A549), prostate (LNCaP), colon (SW-480) and leukaemia (Molt-4) cancer cell lines. The Ataulfo and Haden polyphenolic extracts exhibited cell growth inhibitory potential in all tested cancer cell lines in a dose-dependent manner. The Ataulfo extract exhibited the most potent inhibitory effects in the MDA-MB-231 cells, while the Haden extract displayed the most prominent inhibitory effects in the Molt-4 cells. Fitriasih et al (34) also demonstrated that the treatment of MCF-7 breast cancer cells with a methanol extract of MI leaves induced apoptosis by 
decreasing $\mathrm{Bcl}-2$ expression and increasing Bax expression. In another study, when MDA-MB-231 cells were exposed to polyphenols extracted from MI pulp, cell growth was inhibited and the expression of PI3K signalling-associated miRNAs was modulated (35). Furthermore, Abdullah et al (36) reported that MI seed ethanolic extract induced the apoptosis of MCF-7 breast cancer cells.

Notably, major polyphenols, such as mangiferin, norathyriol and quercetin have been reported to exert inhibitory effects against $\mathrm{P}$-glycoprotein, a member of the adenosine triphosphate binding cassette transporter superfamily responsible for multidrug resistance in human cancers (37). The PI3K/AKT/mTOR signalling pathway is a frequently activated signalling pathway in a range of human cancers (38). Banerjee et al (39) demonstrated that when BT474 breast cancer cells were exposed to MI pulp extracts, the expression of PI3K signalling-associated proteins, such as p-PI3K, p-AKT and AKT was reduced. Furthermore, female athymic $\mathrm{BALB} / \mathrm{c}$ nude mice bearing BT474 tumours, exhibited a reduction in tumour size and PI3K signalling-associated proteins when fed the pulp extract (39). These findings indicate that MI extracts and phytochemicals may have potential for use in the development of drugs for cancer treatment. However, the possible toxic effects of mango extracts and compounds need to be determined and managed before using these as therapeutics for cancer in clinical practice.

\section{Medicinal properties of MZ}

Although MZ has been used in Sri Lankan traditional medicine against several diseases and conditions. including cancer, the scientific validation of its use for cancer treatments was only recently initiated (40). Hexane and chloroform extracts of MZ bark have been reported to exert anticancer effects in breast and ovarian cancer cells in vitro $(40,41)$. Moreover, two new halogenated compounds and a new resorcinolic lipid were isolated from the bark of MZ $(41,42)$. The scientific evidence related to the anticancer effects of MZ extracts and compounds is briefly discussed below.

Anticancer properties exerted by various $M Z$ extracts and isolated compounds. Two new halogenated compounds (chloromangiferamide and bromomangiferic acid), quercetin and catechin (41), as well as a new resorcinolic lipid (42) were isolated from the bark of MZ. Of these compounds, chloromangiferamide have been shown to exert selective anticancer effects in MDA-MB-231 triple-negative breast cancer cells with less cytotoxicity to MCF-10A normal mammary epithelial cells. Furthermore, experiments performed using qPCR assays revealed that chloromangiferamide regulated the expression of genes associated with the cell cycle, apoptosis, topoisomerases, drug metabolism, receptor tyrosine kinase signalling, histone deacetylases (HDAC1-4, 6-8 and 11), protein kinases, phosphatases, growth factors and PI3K signalling in MDA-MB-231 cells (41). The isolated new resorcinolic lipid has been shown to exert potent cytotoxic effects through a mechanism related to oxidative stress in MCF-7 oestrogen receptor positive breast cancer cells (42).

Studies conducted with MZ bark extracts have also demonstrated notable scientific findings, which support its traditional use in cancer treatment. The hexane extract of MZ bark was previously reported to exert cytotoxic effects in breast (MCF-7 and MDA-MB-231) and ovarian (SKOV-3) cancer cells through the induction of apoptosis. The gas chromatographymass spectrometry (GC-MS) analysis of the hexane extract of MZ bark identified certain unknown compounds, which indicated the presence of new phytochemicals in the bark of MZ (40). Furthermore, the chloroform extract of MZ fruit peel induced the apoptosis of MCF-7 breast cancer cells through a mechanism related to oxidative stress, suggesting the potential use of MZ fruit peel as a cost-effective source for anticancer compounds (43). However, in order to elucidate the complete anticancer mechanisms exerted by MZ extracts and isolated compounds, in vivo investigations are necessary to determine the in vivo anticancer efficacy and toxic effects of the MZ extracts.

Preliminary investigations conducted in the authors' laboratories identified that extracts prepared from MZ leaves exerted anticancer effects in breast and lung cancer cells in vitro (unpublished data). In vitro investigations performed using MI and MZ extracts are summarized in Table I, while in vivo investigations performed using various $\mathrm{MI}$ extracts are listed in Table II. The chemical structures of the compounds present in MI and MZ are illustrated in Fig. 2. In addition, the pharmacological activities of various compounds isolated from MI and MZ are summarised in Table III. A comparison of the anticancer activities of various MI and MZ extracts is presented in Table IV. Furthermore, the potential efficacy of chloromangiferamide to target HDAC genes in MDA-MB-231 triple-negative breast cancer cells is illustrated by the schematic diagram in Fig. 3.

\section{Epigenetic modifications in human cancer}

Epigenetic modifications can be defined as heritable alterations of gene expression levels which are independent of DNA sequences (6). Apart from the DNA methylation and histone modifications, microRNAs (miRNAs/miRs) also contribute to the epigenetic regulation of gene expression (78). It has been reported that the regulation of epigenetic processes is largely controlled by the environmental conditions, lifestyle, developmental stages, pathological conditions and diet $(79,80)$. During the development and cellular differentiation of an organism, cell type-specific epigenetic patterns developed define normal pattern of gene functions in each cell type (80). Furthermore, it has been reported that epigenetic modifications play a key role in the development of a number of diseases, including cancer, autoimmune diseases, neurodegenerative diseases and psychiatric disorders $(81,82)$. Therefore, understanding the role of epigenetics in human diseases and identification potential drug targets which can target aberrant epigenetic alterations will be extremely beneficial.

Chromatin structure. Nucleic acid material of eukaryotes consists of DNA and histone proteins (83). Histone proteins are found as octamers and are wrapped by 1.65 turns of DNA. These octamers consist of two copies of histone subunits known as $\mathrm{H} 2 \mathrm{~A}, \mathrm{H} 2 \mathrm{~B}, \mathrm{H} 3$ and $\mathrm{H} 4$. The N-terminal tails of these subunits contain higher amounts of lysine resulting in an overall positive charge. The chromatin structure functions as a 
Table I. In vitro and in vivo studies conducted with different extracts/parts of Mangifera indica and Mangifera zeylanica.

\begin{tabular}{|c|c|c|c|c|c|}
\hline Plant & Plant part and extract & Disease/condition & Cell line/s used & Pathway/s & (Refs.) \\
\hline \multirow[t]{10}{*}{$\begin{array}{l}\text { Mangifera } \\
\text { indica }\end{array}$} & $\begin{array}{l}\text { Ethanol and PBS } \\
\text { extracts of peel }\end{array}$ & Colorectal cancer & $\begin{array}{l}\text { HT29, Caco-2 } \\
\text { and HCT116 }\end{array}$ & $\begin{array}{l}\gamma \mathrm{H} 2 \mathrm{AX} \text {-mediated genotoxicity } \\
\text { and apoptosis }\end{array}$ & (44) \\
\hline & $\begin{array}{l}\text { Ethanol extract of } \\
\text { seed kernel }\end{array}$ & Breast cancer & $\begin{array}{l}\text { MDA-MB-231 } \\
\text { and MCF-7 }\end{array}$ & $\begin{array}{l}\text { Increments in neutral red uptake } \\
\text { and lactate dehydrogenase release } \\
\text { and enhanced cytotoxicity }\end{array}$ & $(45,46)$ \\
\hline & $\begin{array}{l}\text { Aqueous extract of } \\
\text { fruits }\end{array}$ & Leukaemia & $\begin{array}{l}\text { B-lymphocytes } \\
\text { from patients }\end{array}$ & $\begin{array}{l}\text { Intrinsic pathway of apoptosis and } \\
\text { induction of oxidative stress }\end{array}$ & $(47)$ \\
\hline & $\begin{array}{l}\text { Ethanol extract of } \\
\text { seed }\end{array}$ & Breast cancer & $\mathrm{MCF}-7$ & $\begin{array}{l}\text { Upregulation of Bax, cytochrome } \\
\text { c, p53 and caspases, } \\
\text { Reduction of GSH and Bcl- } 2 \text { levels } \\
\text { and induction of oxidative stress }\end{array}$ & $\begin{array}{l}(36) \\
(36)\end{array}$ \\
\hline & $\begin{array}{l}\text { Ethanol }(80 \%) \\
\text { extract of pomace }\end{array}$ & $\begin{array}{l}\text { Malignant } \\
\text { tumours }\end{array}$ & $\begin{array}{l}\text { HepG2, MCF-7, } \\
\text { A549, HeLa, } \\
\text { A2780, HCT-116 } \\
\text { and BGC-823 }\end{array}$ & Induction of apoptosis & $(48)$ \\
\hline & $\begin{array}{l}\text { Ethanol }(80 \%) \\
\text { extract of peel }\end{array}$ & Breast cancer & MCF-7 & $\begin{array}{l}\text { Downregulation of CYP19A1 } \\
\text { leading to decreased aromatase } \\
\text { activity }\end{array}$ & (49) \\
\hline & $\begin{array}{l}\text { Methanol extract } \\
\text { of peel }\end{array}$ & Breast cancer & MCF-7 & Inhibitory effects on $\mathrm{Ca}^{2+}$ channels & $(50)$ \\
\hline & & & BT474 & $\begin{array}{l}\text { Suppression of the PI3K/AKT } \\
\text { pathway }\end{array}$ & $(39)$ \\
\hline & & & & $\begin{array}{l}\text { Modulation of the miR-126 } \\
\text { expression }\end{array}$ & $(39)$ \\
\hline & Mango beverage & $\begin{array}{l}\text { Inflammation in } \\
\text { intestinal colitis }\end{array}$ & CCD-18Co & $\begin{array}{l}\text { Modulation of the miR-126/PI3K/ } \\
\text { AKT/mTOR axis }\end{array}$ & $(51)$ \\
\hline \multirow[t]{2}{*}{$\begin{array}{l}\text { Mangifera } \\
\text { zeylanica }\end{array}$} & $\begin{array}{l}\text { Peel chloroform } \\
\text { extract }\end{array}$ & Breast cancer & MCF-7 & Induction of oxidative stress & $(43)$ \\
\hline & $\begin{array}{l}\text { Hexane extract } \\
\text { of bark }\end{array}$ & $\begin{array}{l}\text { Breast and } \\
\text { ovarian cancer }\end{array}$ & $\begin{array}{l}\text { MCF-7, } \\
\text { MDA-MB-231 } \\
\text { and SKOV-3 }\end{array}$ & Induction of apoptosis & $(42)$ \\
\hline
\end{tabular}

protective mechanism for genetic information and regulatory mechanism to control the access to enzymes and proteins necessary for DNA replication and gene expression (84).

DNA methylation and its role in human cancers. DNA methylation exclusively takes place in the cytosine bases of $\mathrm{CpG}$ dinucleotides in the human genome (85). Short $\mathrm{CpG}$ contents (0.5-4 kb), referred to as $\mathrm{CpG}$ islands, are commonly found in the human gene promoter regions (86). The epigenetic silencing of tumour suppressor genes (for example $C D K N 1 C, C D K N 2 A$, RUNX3, WT1, FOXA2, DAPK, TMS1, BCL2, HOXD11, GPC3, $L A M A 3$ and $L K B 1$ ) due to the hypermethylation of $\mathrm{CpG}$ islands is frequently observed in human cancers (86). Several oncogenes are upregulated through promoter hypermethylation (6). For example, the promoter of the gene SOSTDC1, which encodes for a bone morphogenetic protein, is frequently upregulated through hypermethylation $(85,86)$. The FLT4 gene, that encodes a tyrosine kinase receptor for vascular endothelial growth factors C and D, is frequently upregulated through promoter hypermethylation. $C Y B A$, a gene that encodes for cytochrome B light chain is also upregulated through DNA hypermethylation (86). $A P C$ is a tumour suppressor gene known to regulate the Wnt signalling pathway. In colorectal cancer the hypermethylation of the $A P C$ gene promoter induces the downregulation of $A P C$ (87). The RASAL2 gene that encodes for Ras-GTPase-activating protein 2 is also upregulated through promoter hypomethylation in distinct human cancers (88). DNA methyl transferase inhibitors are useful drugs in cancer treatments. Deoxycytidine is one of the very first drugs which undergoes a series of phosphorylation steps and incorporates into $\mathrm{CpG}$ sites of DNA, leading to the formation of covalent bonds between DNA methyl transferase 1 (DNMT1) catalytic sites (89,90). 5-Aza-2'-deoxycytidine is a Food and Drug Administration (FDA)-approved DNMT inhibitor used in the treatment of myelodysplastic syndromes (91).

Histone modifications in cancer. Histone acetylation is another major epigenetic modification event, which involves 
<smiles>O=C1OC(Cc2c(O)cc(O)cc2Oc2cc(O)cc(O)c2)C1c1ccc(O)c(O)c1</smiles>

$(-)$-Epicatechin gallate<smiles>Oc1cc(O)c2c(c1)OC(c1ccc(O)c(O)c1)[C@H](O)C2</smiles>

(+)-Catechin

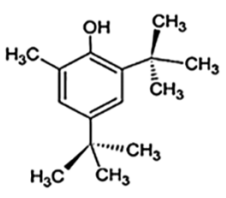

4,6-di (1,1-dimethylethyl)2-methylphenol<smiles>O=C(O)c1cc(O)c(O)c(O)c1</smiles>

Gallic acid

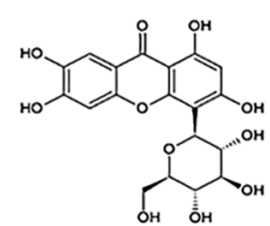

Isomangiferin

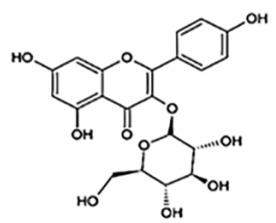

Kaempferol-3-o-glucoside

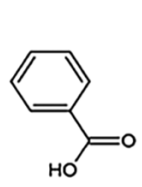

Benzoic acid<smiles>O=C(/C=C/c1ccc(O)c(O)c1)O[C@H]1C[C@@](O)(C(=O)O)C[C@H](O)[C@H]1O</smiles>

Chlorogenic acid

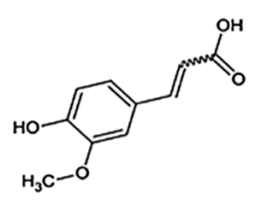

Ferulic acid

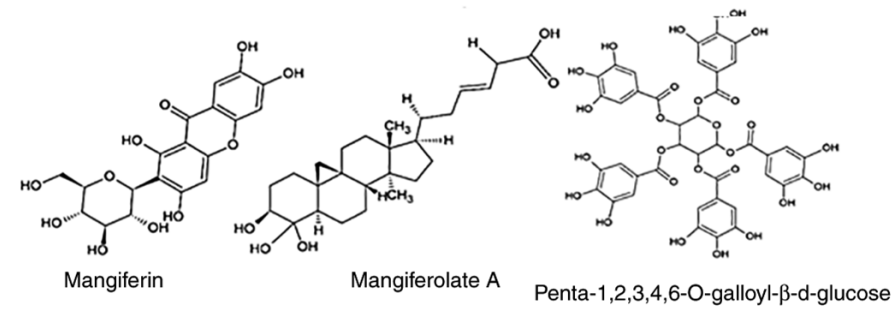<smiles>O=C(O)c1ccc(O)c(O)c1</smiles>

Protocatechuic acid<smiles>O=c1c(O)c(-c2ccc(O)c(O)c2)oc2cc(O)cc(O)c12</smiles>

Quercetin

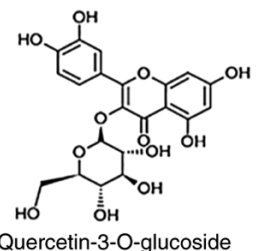<smiles>O=c1c(OC2OCC(O)C(O)C2O)c(-c2ccc(O)c(O)c2)oc2cc(O)cc(O)c12</smiles>

Quercetin-3-0-xyloside

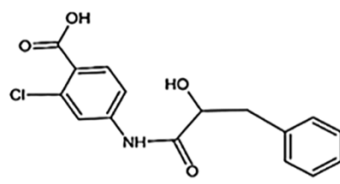

Chloro-mangiferamide
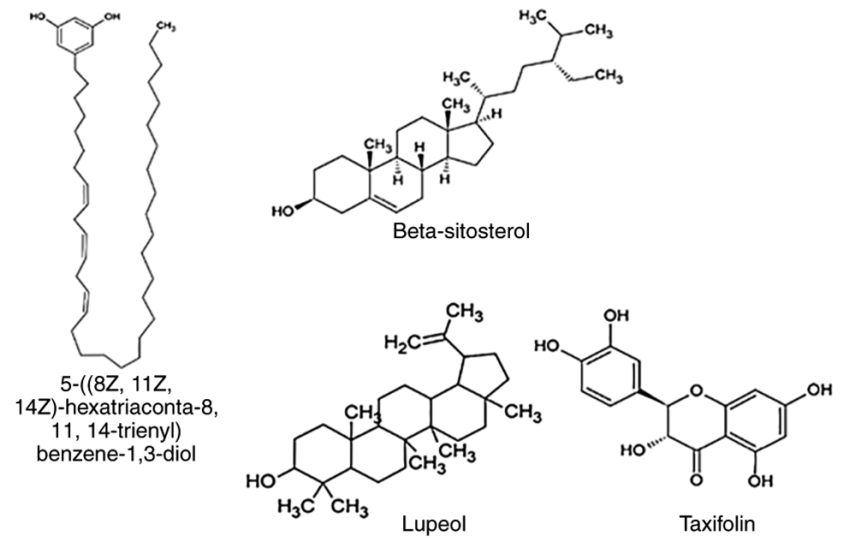

Figure 2. Chemical structures of various compounds found in Mangifera indica and Mangifera zeylanica.

Table II. In vivo pharmacological activities of various extracts/major compounds of Mangifera indica.

\begin{tabular}{|c|c|c|c|c|}
\hline Extract & Disease/condition & Test animals & Effects & (Refs.) \\
\hline $\begin{array}{l}\text { Aqueous extract } \\
\text { of leaves }\end{array}$ & Diabetics & Wistar rat & $\begin{array}{l}\text { Increment of insulin sensitivity and levels in } \\
\text { diabetic animals }\end{array}$ & $(52)$ \\
\hline $\begin{array}{l}\text { Ethanol extract } \\
\text { of leaves }\end{array}$ & Obesity & Wistar rat & $\begin{array}{l}\text { Modulation of endocannabinoid system and } \\
\text { PPAR } \gamma \text { expression leading to the control of } \\
\text { metabolic syndrome and obesity }\end{array}$ & (24) \\
\hline Mango polyphenols & $\begin{array}{l}\text { Anti-tumorigenic } \\
\text { properties }\end{array}$ & $\begin{array}{l}\text { Female athymic } \\
\text { BALB/c nude mice }\end{array}$ & $\begin{array}{l}\text { Suppression of the PI } 3 \mathrm{~K} / \mathrm{AKT} \text { pathway; } \\
\text { modulation of miR-126 expression }\end{array}$ & (39) \\
\hline $\begin{array}{l}\text { Stem bark extract } \\
\text { and leaf extract } \\
\text { (ethanol) }\end{array}$ & Obesity & $\begin{array}{l}\text { Male Wistar } \\
\text { rats }\end{array}$ & $\begin{array}{l}\text { Inhibition of pancreatic lipase and lipoprotein } \\
\text { lipase led to reduce the lipid uptake in } \\
\text { intestine and free fatty acids in adipose tissue }\end{array}$ & (27) \\
\hline \multirow[t]{2}{*}{ Mangiferin } & $\begin{array}{l}\text { Iron overload in } \\
\text { animal models }\end{array}$ & $\begin{array}{l}\text { Sprague-Dawley } \\
\text { rats }\end{array}$ & $\begin{array}{l}\text { Reduction of iron accumulation in liver, } \\
\text { spleen and heart }\end{array}$ & $(53)$ \\
\hline & $\begin{array}{l}\text { Cisplatin-induced } \\
\text { nephrotoxicity }\end{array}$ & $\begin{array}{l}\text { Male Wistar albino } \\
\text { rats }\end{array}$ & $\begin{array}{l}\text { Protection of kidney cells from apoptosis } \\
\text { through modulation of the MAP kinase } \\
\text { pathway }\end{array}$ & (54) \\
\hline
\end{tabular}

the acetylation of lysine residues at the $\varepsilon$-amino groups of histones (92). This epigenetic modification is controlled by two different groups of enzymes known as histone acetyl transferases (HATs) and histone deacetylases (HDACs). HATs transfer the acetyl group from Acetyl-Co A to amino acid group of the targeted lysine residues found in the histone tails, while HDACs counteract the actions of HATs (92).

Based on the structural homology, HATs are classified into three different families known as Gcn5-related N-acetyltransferases (GNATs), MOZ, Ybf2, Sas2, TIP60 
Table III. Compounds isolated from different Mangifera species and their effects on cancer signalling pathways.

\begin{tabular}{|c|c|c|c|c|}
\hline Mangifera species & Identified compounds & Cell lines used & Pathway/s affected & (Refs.) \\
\hline \multirow[t]{16}{*}{ Mangifera indica } & (-)-Epicatechin gallate & $\begin{array}{l}\text { SCC7, Tu177 } \\
\text { and Tu212 }\end{array}$ & Inhibition of the canonical Wnt pathway & $(55,56)$ \\
\hline & & & Downregulation of cyclin D1 expression & $(55,56)$ \\
\hline & $\begin{array}{l}\text { 4,6-di (1,1-Dimethylethyl)- } \\
\text { 2-methylphenol }\end{array}$ & $\begin{array}{l}\text { MCF-7 and } \\
\text { MDA-MB-231 }\end{array}$ & Apoptosis and oxidative stress & $(12,45)$ \\
\hline & Chlorogenic acid & $\begin{array}{l}\text { HCT116 } \\
\text { HT29 }\end{array}$ & $\begin{array}{l}\text { Generation of reactive oxygen species } \\
\text { Cell cycle arrest at } S \text { phase }\end{array}$ & $\begin{array}{l}(57,58) \\
(57,58)\end{array}$ \\
\hline & Ferulic acid & HeLa and Caski & Downregulation of MMP-9 expression & $(59)$ \\
\hline & Gallic acid & SMMC-7721 & Induction of apoptosis & $(60)$ \\
\hline & Isomangiferin & MCF-7 & $\begin{array}{l}\text { Induction of apoptosis by inhibition } \\
\text { of VEGFR } 2 \text { kinase }\end{array}$ & $(61)$ \\
\hline & $\begin{array}{l}\text { Kaempferol } 3-O-\beta \text { - } \\
\text { D-glucoside }\end{array}$ & HL-60 & $\begin{array}{l}\text { Intrinsic pathway of apoptosis } \\
\text { Generation of reactive oxygen species } \\
\text { Induction of JNK/SAPK and ERK } 1 / 2 \\
\text { signalling }\end{array}$ & $(56,62)$ \\
\hline & Mangiferin & HL-60 & $\begin{array}{l}\text { Inhibition of ATR, Chk1, Wee1, Akt, } \\
\text { and Erk1/2 phosphorylation }\end{array}$ & $(63)$ \\
\hline & & K562 & Overexpression of BCR and ABL & (64) \\
\hline & & OVCAR3 & $\begin{array}{l}\text { Induction of apoptosis through the } \\
\text { Notch3 pathway }\end{array}$ & $(65)$ \\
\hline & $\begin{array}{l}\text { Penta-1,2,3,4,6-O-galloyl- } \\
\beta \text {-d-glucose }\end{array}$ & LNCaP & Apoptosis & $(33,66)$ \\
\hline & Protocatechuic acid & HL-60 & $\begin{array}{l}\text { Suppression of Bcl-2 and upregulation } \\
\text { of Bax }\end{array}$ & $(33)$ \\
\hline & Quercetin & MGC803 & $\begin{array}{l}\text { Modulation of the PI3K/Akt/mTOR } \\
\text { pathway }\end{array}$ & $(67)$ \\
\hline & & Nalm6 & Cell cycle arrest at $\mathrm{S}$ phase & (68) \\
\hline & & $\begin{array}{l}\text { HCT } 116 \text { and } \\
\text { HT29 }\end{array}$ & Suppression of HSP27 & $(57,68)$ \\
\hline $\begin{array}{l}\text { Mangifera } \\
\text { zeylanica }\end{array}$ & Chloro-mangiferamide & MDA-MB-231 & $\begin{array}{l}\text { Apoptosis, downregulation of protein } \\
\text { kinases, histone deacetylases and } \\
\text { heat-shock proteins }\end{array}$ & $(41)$ \\
\hline Mangifera casturi & Lupeol & HCT116 & Canonical Wnt pathway & $(69,70)$ \\
\hline Mangifera pajang & Taxifolin & $\begin{array}{l}\text { HCT } 119 \text { and } \\
\text { HT29 }\end{array}$ & Canonical Wnt pathway and cell cycle & $(71,72)$ \\
\hline
\end{tabular}

(MYST) and orphan [p300/CREB binding protein (CBP) and nuclear receptors] (93). These enzymes neutralize positive charges of the histone proteins, resulting in weakened interactions between histones and DNA, rendering chromatin less condensed and DNA more accessible to transcription factors (94). Histone acetylation is however targeted to specific regions of DNA through sequences specific co-factors of HATs, including CBP, p300, MYST, and GNAT. The deacetylation of histones leads to condensed chromatin, resulting in the transcriptional silencing of genes (95).

Apart from the acetylation of histones, several other modifications, such as the phosphorylation, methylation and ubiquitination of histone subunits have also been identified. Research performed using normal tissues, tumours and mouse models has reported that the loss of acetylated Lys16 (K16-H4) of histone $\mathrm{H} 4$ is a frequent event in human cancers (95). Moreover, a reduction in histone acetylation has been shown to be associated with invasion and metastasis in gastrointestinal tumours (95). Mutations, such as missense mutations, truncations, translocations and frame shift mutations of different families of HATs have been identified in several human cancers, including colorectal, head, neck, breast and lung cancers (96).

Investigations carried out with histone deacetylase inhibitors (HDACis) have proven the role of HDACs in the regulation of p21 protein (97). p21 Protein is a cyclin-dependant kinase inhibitor which inhibits cyclin D1, A and E. The inhibition of p21 leads to cell cycle arrest at the G1 or G2/M phases (98). In prostate cancer cells, exposure to trichostatin A, an HDAC 
Table IV. Comparison of anticancer activities of different parts of MI and MZ and grapes (Vitis vinifera).

\begin{tabular}{|c|c|c|c|c|}
\hline Plant part & Mangifera indica & Mangifera zeylanica & Vitis vinifera & (Refs.) \\
\hline Bark & $\begin{array}{l}\text { Induces apoptosis of MCF-7 breast } \\
\text { cancer cells }\end{array}$ & $\begin{array}{l}\text { Induces apoptosis of MCF-7 } \\
\text { cells }\end{array}$ & Not reported & $(42,73)$ \\
\hline Leaves & $\begin{array}{l}\text { Induces apoptosis of } \mathrm{MCF}-7 \text { breast } \\
\text { cancer cells by upregulating } \mathrm{Bax} \\
\text { and downregulating } \mathrm{Bcl}\end{array}$ & $\begin{array}{l}\text { Induces apoptosis of } \\
\text { NCI-H292 lung cancer cells } \\
\text { by upregulating p53, Bax and } \\
\text { downregulating Survivin } \\
\text { (unpublished data) }\end{array}$ & $\begin{array}{l}\text { Water and ethanol extracts } \\
\text { increase the expression of } \\
\text { Bax in HUVECs and HepG } 2 \\
\text { liver cancer cells }\end{array}$ & $(34,74)$ \\
\hline Fruit pulp & $\begin{array}{l}\text { Mango beverage inhibits growth } \\
\text { in CCD-18Co by modulating } \\
\text { miR-126/PI3K/AKT/mTOR axis }\end{array}$ & Not reported & $\begin{array}{l}\text { Induces autophagy in MCF-7 } \\
\text { breast cancer cells }\end{array}$ & $(39,75)$ \\
\hline Seed & $\begin{array}{l}\text { Ethanolic extract enhances } \\
\text { cytotoxicity to MCF- } 7 \text { and } \\
\text { MDA-MB- } 231 \text { breast cancer cells }\end{array}$ & $\begin{array}{l}\text { Hexane extract shows } \\
\text { cytotoxicity to NCI-H292 lung } \\
\text { cancer cells (unpublished data) }\end{array}$ & $\begin{array}{l}\text { Increases apoptosis in DU145 } \\
\text { and LNCaP prostate cancer } \\
\text { cells }\end{array}$ & $(36,76)$ \\
\hline $\begin{array}{l}\text { Fruit } \\
\text { peel/skin }\end{array}$ & $\begin{array}{l}\text { Ethanol extract inhibits MCF-7 } \\
\text { breast cancer cell growth by } \\
\text { downregulating the CYP19A1 } \\
\text { gene. Methanol extract inhibits } \\
\mathrm{Ca}^{2+} \text { channels in MCF- } 7 \text { cells }\end{array}$ & $\begin{array}{l}\text { Chloroform extract induces } \\
\text { oxidative stress in MCF-7 } \\
\text { breast cancer cells }\end{array}$ & $\begin{array}{l}\text { Induces apoptosis of prostate } \\
\text { cancer cells by targeting } \\
\text { the phosphatidylinositol } \\
\text { 3-kinase-Akt and mitogen- } \\
\text { activated protein kinase } \\
\text { survival pathways }\end{array}$ & $(43,49,77)$ \\
\hline
\end{tabular}

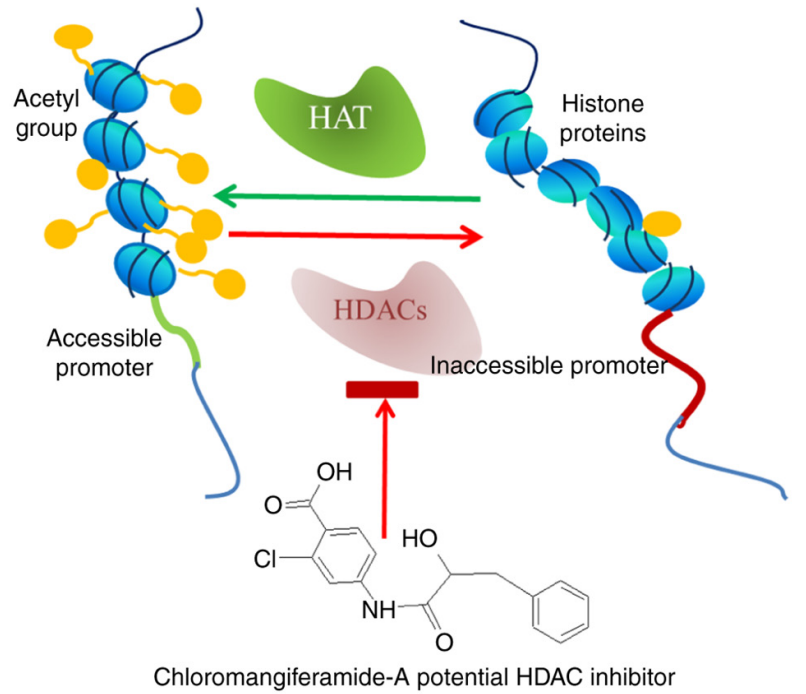

Figure 3. Schematic diagram of the potential efficacy of chloromangiferamide, isolated from the bark of Mangifera zeylanica bark, to target HDACs in MDA-MB-231 triple negative breast cancer cells. Chloromangiferamide isolated from the bark of MZ has been reported to reduce the expression of histone deacetylases (HDAC1-4, 6-8 and 11) in MDA-MB-231 triple-negative breast cancer cells and to exert less cytotoxic effects in normal mammary epithelial cells (40). Histone acetylation is another major epigenetic modification event, which involves acetylation of lysine residues at the $\varepsilon$-amino groups of histones. This epigenetic modification is controlled by two different groups of enzymes known as HATs and HDACs. HATs transfer the acetyl group from the Acetyl-Co A to amino acid group of the targeted lysine residues found in the histone tails, while HDACs counteract the actions of HATs. HDAC inhibitors can correct aberrant acetylation profiles in cancer. HDACs, histone deacetylases; HATs, histone acetyl transferases.

inhibitor, has been found to induce the activation of p-glycoprotein expression through the modulation of the histone markers, H3K4me2, H3K4me3, H3K9Ac, H4Ac and H3Ac, indicating an involvement of an epigenetic mechanism in the regulation of p-glycoprotein expression (99).

HDACis, also known as chromatin-modifying agents, have been identified as a promising class of anticancer agents. HDACis have the ability to re-establish dysregulated acetylation profiles of cancer cells and re-activate the expression of epigenetically silenced tumour suppressor genes, allowing cancer cells to undergo programmed cell death (apoptosis) (6). To date, several pan or isoform specific HDACis (natural and synthetic) have been developed and, these HDACis allow for the identification of the role of various HDACs in tumorigenesis (100). Vorinostat (SAHA) for the treatment of cutaneous T-cell lymphomas (CTCL), panobinostat (LBH-589) for the treatment of multiple myeloma, belinostat (PXD101) for the treatment of peripheral T-cell lymphomas (PTCL) and romidepsin for the treatment of CTCL and PTCL are the only four FDA-approved HDACis in clinical use to date (100). Natural compounds, such as curcumin, epigallocatechin gallate, sulforaphanes, kaempferol, resveratrol and butein are some examples for natural HDACis (7).

miRNAs. A group of short RNA molecules (18-22 nucleotides), known as miRNAs, also contribute to the epigenetic regulation of gene expression (101). miRNAs are transcribed by RNA polymerase II to yield primary-miRNAs (pri-miRNAs), which are then cleaved into 65-70 nucleotide-long hairpin RNA duplexes by DROSHA and PASHA (microprocessors) $(101,102)$. These are then exported to the cytoplasm and further cleaved by a protein complex known as Dicer to generate functional miRNAs. A complex comprised of miRNAs and a protein known as RISC (RNA induced silencing complex) bind to the target mRNA and degrade it, causing gene silencing (103). 
miRNAs play crucial roles in the development, apoptosis, cell differentiation and proliferation under normal conditions (104).

There is experimental evidence to indicate that a considerable number of miRNAs can play oncogenic or tumour-suppressive roles (105). The upregulation of oncogenic miRNAs, also referred as oncomirs, is frequently observed in a range of human cancers (105). It has been reported that any functional irregularity in the expression and function of tumour suppressor miRNAs can cause tumorigenesis (105). The Let-7 family miRNAs (let-7a, let-7b and let-7g), miR-205, members of the miR-200 family (miR-200a, b and c, miR141 and miR-429), miR-200c, miR-145 and miR-142-3p have been reported to function as tumour suppressor miRNAs, while oncogenic roles of miRNAs, such as miR-21, miR-10a, miR-10b, miR-155, miR-17-92, miR-17-5p, miR-27a, miR-96 and miR-182 have also been identified $(98,106,107)$. It has been found that epigenetic modifications, such as histone deacetylation in promoter sites and DNA methylation in $\mathrm{CpG}$ islands cause alternations in mRNA expression. Therefore, epigenetic mechanisms provide promising drug targets since DNA-demethylating agents and HDACis can be used to re-establish mRNA expression implicated due to epigenetic alternations (99). Several miRNAs have also been identified to play a regulatory role in cancer stem cells (CSCs). For example, the Let-7 family miRNAs have been reported to play a role in CSC differentiation (99).

Mango compounds as epigenetic modifiers. Several mango compounds have been reported to function as epigenetic modulators. Epicatechin gallate has been found to upregulate HDAC5 and HDAC7, while downregulating HDAC 1 and HDAC3. Moreover, the DNMT inhibitory activities of catechin have also been reported (108).

Experiments performed using $\mathrm{A} / \mathrm{J}$ mice have revealed that epicatechin gallate leads to a significant elevation in the levels of miRNAs related to lung tumours induced by 4-(meth ylnitrosamino)-1-(3-pyridyl)-1-butanone. These miRNAs include mmu-miR-2137, mmu-miR-449a, mmu-miR-144, mmu-miR-193,mmu-miR-5030 and mmu-miR-2861. Moreover, the downregulation of mmu-miR-969, mmu-miR-449c, mmu-miR-7a, mmu-miR-205 and mmu-miR-218 has also been observed due to the exposure to epicatechin gallate (109).

A previous study performed using ATDC5 cells revealed that mangiferin upregulated miR-181a expression. The upregulation of miR-181a resulted in protection from lipopolysaccharide-induced cell damage, by suppressing the levels of PTEN and the NF- $\kappa$ B pathway (110). Another study performed using glioma cells demonstrated that mangiferin upregulated miR-15b expression, resulting in the suppression of MMP-9 in U87 cells, indicating the ability of mangiferin to reduce metastasis (111).

\section{Phytochemicals common to both $\mathrm{MI}$ and $\mathrm{MZ}$}

Mangiferin is one of the well-known phytochemicals found in MI. Mangiferin has also been isolated from the bark of MZ (112). The therapeutic potential of mangiferin has also been investigated. Mangiferin has been found to exert preventive roles against mitochondrial depolarization, oxidative stress and neuronal death (112). Lemus-Molina et al (113) demonstrated that the consumption of MI extracts rich in mangiferin attenuated neuronal death during normal aging and in neurodegenerative disorders. Another study reported that mangiferin exerted potent antioxidant effects (114). Mangiferin has also been reported to exert cytotoxic effects in cancer cells $(63,64)$. Another study states that mangiferin can protect rats from cardiac and renal damage (115). Rajendran et al (116) demonstrated cytoprotective and antioxidant effects of mangiferin. Apart from these effects, mangiferin is capable of antagonizing the cytopathic effect of HIV in vitro (117). Furthermore, a previous study demonstrated that mangiferin induced apoptosis through the $\mathrm{PKC} / \mathrm{NF}-\kappa \mathrm{B}$ pathway and the cell cycle arrest of multiple myeloma cells (118). Biersack (119) reported that mangiferin can mediate the regulation of tumor suppressor miRNAs including miR-15b and miR-182.

Apart from mangiferin, gallic acid and quercetin are commonly found in the genus Mangifera. In a previous study, Ediriweera et al (41) isolated quercetin from the bark of MZ. The anti-proliferative effects of gallic acid mediated by the epigenetic regulation of miRNAs have been reported in glioma T98G cells (120). Sundaram et al (121) demonstrated that quercetin exerted anti-proliferative effects in human cervical cancer cells. Quercetin treatment has been shown to decrease the activity of DNMTs, increasing the global acetylation of $\mathrm{H} 3$ and $\mathrm{H} 4$, and induce the enrichment of acetylated histone $\mathrm{H} 3$ and $\mathrm{H} 4$ to the promoters of genes related to apoptosis (121). Previously, PLGA [poly(lactic-co-glycolic acid)]-loaded gold nanoparticles prepared with quercetin were found to exert anti-proliferative effects in hepatocellular carcinoma cells through down-regulation of HDAC-Akt activities (122). On the whole, these studies indicate that phytochemicals from MI and $\mathrm{MZ}$ are useful epigenetic regulators.

\section{Conclusion}

MI is a pharmacologically and phytochemically diverse plant. Extracts prepared from different parts (skin and pulp of the fruit, leaves, bark, roots and seeds) of MI are used in traditional medicine for the treatment of numerous diseases and ailments. The fruits of MI are rich in vitamins, essential amino acids and a range of polyphenols. In vitro and in vivo experimental evidence indicates that different extracts and major phytochemicals of MI can lead to beneficial pre-clinical outcomes against several health conditions, including cancer (1). Mango phytochemicals and mango extracts have been reported to target aberrantly expressed cancer signalling pathways (e.g., the PI3K/AKT/mTOR signalling pathway) $(1,39)$. Some major mango polyphenols have the ability to re-store dysregulated epigenetic profiles in human cancers. Of note, in vivo experimental evidence demonstrates that MI extracts and some major compounds exert less toxic effects, justifying their use in human systems without causing adverse side-effects (14-19,21,22,25,26,29).

MZ is an endemic mango species found in Sri Lanka. The bark of MZ has been used in Sri Lankan traditional medicine for the treatment of a number of diseases, including cancer. Efforts have been made to validate its traditional use scientifically. For example, hexane and chloroform extracts of its bark and certain novel compounds isolated from the bark of 
MZ have been reported to exert anticancer effects in breast and ovarian cancer cells $(41,42)$. Moreover, peel chloroform extract prepared from $\mathrm{MZ}$ fruits also exerts anticancer effects, indicating that the anticancer potential of $\mathrm{MZ}$ is not limited to its bark. However, to obtain a clear anticancer profile for $\mathrm{MZ}$, in vivo studies with distinct mouse models for cancer and the evaluation of the toxic effects of MZ extracts are necessary. Dysregulated epigenetic events have been reported to drive tumorigenesis. A number of phytochemicals have exhibited the ability to re-establish aberrant epigenetic profiles in a range of human cancers. The present review article highlighted the ability of certain mango compounds to function as epigenetic modifiers.

\section{Acknowledgements}

Not applicable.

\section{Funding}

The present study was supported by the Department of Science and Technology, Government of India (grant no. DST/INT/SL/P-12/2016) and the Ministry of Science, Technology and Research, Sri Lanka (grant no. MSTR/TRD/AGR/3/02/08).

\section{Availability of data and materials}

Not applicable.

\section{Authors' contributions}

All authors (IS, AV, NP, MKE, DN, SRS, KHT and VV) contributed to the conceptualization, writing, drafting, revising, editing and reviewing of the manuscript. Data authentication is not applicable. All authors have read and approved the final manuscript.

\section{Ethics approval and consent to participate}

Not applicable.

\section{Patient consent for publication}

Not applicable.

\section{Competing interests}

The authors declare that they have no competing interests.

\section{References}

1. Ediriweera MK, Tennekoon KH and Samarakoon SR: A review on ethnopharmacological applications, pharmacological activities, and bioactive compounds of Mangifera indica (mango). Evid Based Complement Alternat Med 2017: 6949835, 2017.

2. Yadav D and Singh S: Mango: History origin and distribution. J Pharmacogn Phytochem 6: 1257-1262, 2017.

3. Maldonado-Celis ME, Yahia EM, Bedoya R, Landázuri P, Loango N, Aguillón J, Restrepo B and Guerrero Ospina JC: Chemical composition of mango (Mangifera indica L.) fruit: Nutritional and phytochemical compounds. Front Plant Sci 10 1073, 2019.
4. Weerarathne WAPG, Samarajeewa PK and Nilanthi RMR: Genetic diversity of etamba in Sri Lanka. J Trop Agri Res Ext 8: 107-112, 2005.

5. IUCN. The IUCN Red List of Threatened Species. Version 2021-3. 2021. https://www.iucnredlist.org/species/31400/9630295. Accessed January 21, 2022.

6. Ediriweera MK, Tennekoon KH and Samarakoon SR: Emerging role of histone deacetylase inhibitors as anti-breast-cancer agents. Drug Discov Today 24: 685-702, 2019.

7. Thakur VS, Deb G, Babcook MA and Gupta S: Plant phytochemicals as epigenetic modulators: Role in cancer chemoprevention. AAPS J 16: 151-163, 2014.

8. Ghasemi S: Cancer's epigenetic drugs: Where are they in the cancer medicines? Pharmacogenomics J 20: 367-379, 2020.

9. Shankar E, Kanwal R, Candamo M and Gupta S: Dietary phytochemicals as epigenetic modifiers in cancer: Promise and challenges. Semin Cancer Biol 40-41: 82-99, 2016.

10. Princwill-Ogbonna IL, Ogbonna PC and Ogujiofor IB: Proximate composition, vitamin, mineral and biologically active compounds levels in leaves of Mangifera indica (Mango), Persea Americana (Avocado pea), and Annona muricata (Sour Sop). J Appl Sci Environ Manage 23: 65, 2019.

11. Dhital KS: Phytochemical screening and antioxidant activities of Mangifera indica leaves grown in temperate region of the Nepal. J Pharmacogn Phytochem 6: 205-209, 2017.

12. Vazquez-Olivo G, Antunes-Ricardo M, Gutiérrez-Uribe JA, Osuna-Enciso T, León-Félix J and Heredia JB: Cellular antioxidant activity and in vitro intestinal permeability of phenolic compounds from four varieties of mango bark (Mangifera indica L.). J Sci Food Agric 99: 3481-3489, 2019.

13. Khumpook T, Saenphet S, Tragoolpua Y and Saenphet K: Anti-inflammatory and antioxidant activity of Thai mango (Mangifera indica Linn.) leaf extracts. Comp Clin Path 28: 157-164, 2019.

14. John OR, Yahaya AA and Emmanuel A: Aqueous ethanolic extract of Mangifera indica stem bark effect on the biochemical and haematological parameters of albino rats. Arch Appl Sci Res 4: 1618-1622, 2012.

15. Al Omairi NE, Radwan OK, Alzahrani YA and Kassab RB: Neuroprotective efficiency of Mangifera indica leaves extract on cadmium-induced cortical damage in rats. Metab Brain Dis 33: 1121-1130, 2018.

16. Wattanathorn J, Muchimapura S, Thukham-Mee W, Ingkaninan K and Wittaya-Areekul S: Mangifera indica Fruit extract improves memory impairment, cholinergic dysfunction, and oxidative stress damage in animal model of mild cognitive impairment. Oxid Med Cell Longev 2014: 132097, 2014.

17. Kuganesan $A$, Thiripuranathar $G$, Navaratne $A$ and Paranagama $P$ : Antioxidant and anti-inflammatory activities of peels, pulps and seed kernels of three common mango (Mangifera indical L.) varieties in Sri Lanka. Int. J Pharm Sci Res 8: 70-78, 2017.

18. Hassan M, Khan S, Shaikat A, Hossain M, Hoque M, Ullah M and Islam S: Analgesic and anti-inflammatory effects of ethanol extracted leaves of selected medicinal plants in animal model. Vet World 6: 68-71, 2013.

19. Márquez L: Anti-inflammatory effects of Mangifera indica L. extract in a model of colitis. World J Gastroenterol 16: 4922-4931, 2010.

20. Kim H, Krenek KA, Fang C, Minamoto Y, Markel ME, Suchodolski JS, Talcott ST and Mertens-Talcott SU: Polyphenolic derivatives from mango (Mangifera indica L.) modulate fecal microbiome, short-chain fatty acids production and the HDAC1/AMPK/LC3 axis in rats with DSS-induced colitis. J Funct Foods 48: 243-251, 2018.

21. Márquez L, Pérez-Nievas BG, Gárate I, García-Bueno B, Madrigal JL, Menchén L, Garrido G and Leza JC: Anti-inflammatory effects of Mangifera indica L. extract in a model of colitis. World J Gastroenterol 16: 4922-4931, 2010.

22. Perpétuo GF and Salgado JM: Effect of mango (Mangifera indica, L.) ingestion on blood glucose levels of normal and diabetic rats. Plant Foods Hum Nutr 58: 1-12, 2003.

23. Saleem M, Tanvir M, Akhtar MF, Iqbal M and Saleem A: Antidiabetic potential of Mangifera indica L. cv. Anwar Ratol leaves: Medicinal application of food wastes. Medicina (Kaunas) 55: 353, 2019.

24. Brito LF, Gontijo DC, Toledo RCL, Barcelos RM, de Oliveira AB, Brandão GC, de Sousa LP, Ribeiro SMR, Leite JPV, Fietto LG and de Queiroz JH: Mangifera indica leaves extract and mangiferin modulate CB1 and PPAR $\gamma$ receptors and others markers associated with obesity. J Funct Foods 56: 74-83, 2019. 
25. Gondi $M$ and Prasada Rao UJS: Ethanol extract of mango (Mangifera indica L.) peel inhibits $\alpha$-amylase and $\alpha$-glucosidase activities, and ameliorates diabetes related biochemical parameters in streptozotocin (STZ)-induced diabetic rats. J Food Sci Technol 52: 7883-7893, 2015.

26. Narasimhan A, Chinnaiyan M and Karundevi B: Ferulic acid exerts its antidiabetic effect by modulating insulin-signalling molecules in the liver of high-fat diet and fructose-induced type-2 diabetic adult male rat. Appl Physiol Nutr Metab 40: 769-781, 2015.

27. Moreno DA, Ripoll C, Ilic N, Poulev A, Aubin C and Raskin I: Inhibition of lipid metabolic enzymes using Mangifera indica extracts. J Food Agric Environ 4: 21-26, 2006.

28. Barnes RC, Kim H, Fang C, Bennett W, Nemec M, Sirven MA Suchodolski JS, Deutz N, Britton RA, Mertens-Talcott SU and Talcott ST: Body mass index as a determinant of systemic exposure to gallotannin metabolites during 6-week consumption of mango (Mangifera indica L.) and modulation of intestinal Microbiota in lean and obese individuals. Mol Nutr Food Res 63: 1800512, 2019.

29. Hannan A, Asghar S, Naeem T, Ikram Ullah M, Ahmed I, Aneela S and Hussain S: Antibacterial effect of mango (Mangifera indica Linn.) leaf extract against antibiotic sensitive and multi-drug resistant Salmonella typhi. Pak J Pharm Sci 26: $715-719,2013$

30. Manzur AG, Sm Junior V, Morais-Costa F, Mariano EG, Careli RT, da Silva LM, Coelho SG, de Almeida AC and Duarte ER: Extract of Mangifera indica L. leaves may reduce biofilms of Staphylococcus spp. in stainless steel and teatcup rubbers. Food Sci Technol Int 26: 11-20, 2020

31. Mushore $\mathrm{J}$ and Matuvhunye $\mathrm{M}$ : Antibacterial properties of Mangifera indica on Staphylococcus aureus. Afr J Clin Exp Microbiol 14: 62-74, 2013.

32. Umamahesh K, Ramesh B, Kumar BV and Reddy OV: In vitro anti-oxidant, anti-microbial and anti-inflammatory activities of five Indian cultivars of mango (Mangifera indica L.) fruit peel extracts. J Herb Med Pharmacol 8: 238-247, 2019.

33. Noratto GD, Bertoldi MC, Krenek K, Talcott ST, Stringheta PC and Mertens-Talcott SU: Anticarcinogenic effects of polyphenolics from mango (Mangifera indica) Varieties. J Agric Food Chem 58: 4104-4112, 2010

34. Fitriasih F, Komariyah SM, Sandra F, Pratiwi N and Hidayati DN Mangifera indica L. leaves extract induced intrinsic apoptotic pathway in MCF-7 cells by decreasing Bcl-2 expression and inducing Bax expression. Indones J Cancer Chemoprevention 10: $1,2019$.

35. Arbizu-Berrocal SH, Kim H, Fang C, Krenek KA, Talcott ST and Mertens-Talcott SU: Polyphenols from mango (Mangifera indica L.) modulate PI3K/AKT/mTOR-associated micro-RNAs and reduce inflammation in non-cancer and induce cell death in breast cancer cells. J Funct Foods 55: 9-16, 2019.

36. Abdullah AS, Mohammed A, Rasedee A and Mirghani M: Oxidative stress-mediated apoptosis induced by ethanolic mango seed extract in cultured estrogen receptor positive breast cancer MCF-7 cells. Int J Mol Sci 16: 3528-3536, 2015.

37. Chieli E, Romiti N, Rodeiro I and Garrido G: In vitro effects of Mangifera indica and polyphenols derived on ABCB1/ P-glycoprotein activity. Food Chem Toxicol 47: 2703-2710, 2009

38. Ediriweera MK, Tennekoon KH and Samarakoon SR: Role of the PI3K/AKT/mTOR signaling pathway in ovarian cancer: Biological and therapeutic significance. Semin Cancer Biol 59: 147-160, 2019.

39. Banerjee N,Kim H,Krenek K, Talcott ST and Mertens-Talcott SU: Mango polyphenolics suppressed tumor growth in breast cancer xenografts in mice: Role of the PI3K/AKT pathway and associated microRNAs. Nutr Res 35: 744-751, 2015.

40. Ediriweera MK, Tennekoon KH, Samarakoon SR, Thabrew I and Dilip de Silva E: A study of the potential anticancer activity of Mangifera zeylanica bark: Evaluation of cytotoxic and apoptotic effects of the hexane extract and bioassay-guided fractionation to identify phytochemical constituents. Oncol Lett 11: 1335-1344, 2016.

41. Ediriweera MK, Tennekoon KH, Adhikari A, Samarakoon SR, Thabrew I and de Silva ED: New halogenated constituents from Mangifera zeylanica Hook.f. and their potential anti-cancer effects in breast and ovarian cancer cells. J Ethnopharmacol 189: 165-174, 2016.

42. Ediriweera MK, Tennekoon KH, Samarakoon SR, Adhikari A, Thabrew I and Dilip de Silva E: Isolation of a new resorcinolic lipid from Mangifera zeylanica Hook.f. bark and its cytotoxic and apoptotic potential. Biomed Pharmacother 89: 194-200, 2017.
43. Ediriweera MK, Tennekoon KH, Samarakoon SR, Thabrew I and De Silva ED: Induction of apoptosis in MCF-7 breast cancer cells by Sri Lankan endemic mango (Mangifera zeylanica) fruit peel through oxidative stress and analysis of its phytochemical constituents: Anticancer effects of Mangifera zeylanica Peel. J Food Biochem 41: e12294, 2017.

44. Lauricella M, Lo Galbo V, Cernigliaro C, Maggio A, Palumbo Piccionello A, Calvaruso G, Carlisi D, Emanuele S, Giuliano $M$ and D'Anneo A: The Anti-cancer effect of Mangifera indica L. Peel extract is associated to $\gamma \mathrm{H} 2 \mathrm{AX}$-mediated apoptosis in colon cancer cells. Antioxidants (Basel) 8: 422, 2019

45. Abdullah AS, Mohammed AS, Abdullah R, Mirghani ME and Al-Qubaisi M: Cytotoxic effects of Mangifera indica L. kernel extract on human breast cancer (MCF-7 and MDA-MB-231 cell lines) and bioactive constituents in the crude extract. BMC Complement Altern Med 14: 119, 2014.

46. Yap KM, Sekar M, Seow JL, Gan SH, Bonam SR, Rani NNIM, Lum PT Subramaniyan V, Wu YS, Fuloria NK and Fuloria S: Mangifera indica (Mango): A promising medicinal plant for breast cancer therapy and understanding its potential mechanisms of action. Breast Cancer (Dove Med Press) 13: 471-503, 2021.

47. Ayatollahi A, Rahmati J, Salimi A and Pourahmad J: A comparison of cytotoxic effects of Mangifera indica L. and Juglans RegiaAqueous extract on human chronic Lymphocytic leukemia. Iran J Pharm Res 18: 1843-1853, 2019.

48. Hu H, Zhao Q, Pang Z, Xie J, Lin L and Yao Q: Optimization extraction, characterization and anticancer activities of polysaccharides from mango pomace. Int J Biol Macromol 117: $1314-1325,2018$

49. Shaban NZ, Hegazy WA, Abdel-Rahman SM, Awed OM and Khalil SA: Potential effect of Olea europea leaves, Sonchus oleraceus leaves and Mangifera indica peel extracts on aromatase activity in human placental microsomes and CYP19A1 expression in MCF-7 cell line: Comparative study. Cell Mol Biol (Noisy-le-grand) 62: 11-19, 2016

50. Taing MW, Pierson JT, Shaw PN, Dietzgen RG, Roberts-Thomson SJ, Gidley MJ and Monteith GR: Mango fruit extracts differentially affect proliferation and intracellular calcium signalling in MCF-7 human breast cancer cells J Chem 2015: 613268, 2015.

51. Kim H, Banerjee N, Barnes RC, Pfent CM, Talcott ST, Dashwood RH and Mertens-Talcott SU: Mango polyphenolics reduce inflammation in intestinal colitis-involvement of the miR-126/PI3K/AKT/mTOR axis in vitro and in vivo: Mango polyphenolics suppress colitis. Mol Carcinog 56: 197-207, 2017.

52. Villas Boas GR, Rodrigues Lemos JM, de Oliveira MW, dos Santos RC, Stefanello da Silveira AP, Barbieri Bacha F, Ito CNA, Bortolotte Cornelius E, Brioli Lima F, Sachilarid Rodrigues AM, et al: Aqueous extract from Mangifera indica Linn. (Anacardiaceae) leaves exerts long-term hypoglycemic effect, increases insulin sensitivity and plasma insulin levels on diabetic Wistar rats. PLoS One 15: e0227105, 2020.

53. Estuningtyas A, Setiabudy R, Wahidiyat $P$ and Freisleben HJ: The role of mangiferin in the prevention of experimentally induced iron overload in an animal model. Drug Res (Stuttg) 69: 234-240, 2019.

54. Sahu AK, Verma VK, Mutneja E, Malik S, Nag TC, Dinda AK, Arya DS and Bhatia J: Mangiferin attenuates cisplatin-induced acute kidney injury in rats mediating modulation of MAPK pathway. Mol Cell Biochem 452: 141-152, 2019.

55. Lim YC, Lee SH, Song MH, Yamaguchi K, Yoon JH, Choi EC and Baek SJ: Growth inhibition and apoptosis by (-)-epicatechin gallate are mediated by cyclin D1 suppression in head and neck squamous carcinoma cells. Eur J Cancer 42: 3260-3266, 2006.

56. Coelho EM, de Souza MEAO, Corrêa LC, Viana AC de Azevêdo LC and dos Santos Lima M: Bioactive compounds and antioxidant activity of mango peel liqueurs (Mangifera indica L.) produced by different methods of maceration. Antioxidants (Basel) 8: 102, 2019.

57. Abbasi AM, Guo X, Fu X, Zhou L, Chen Y, Zhu Y, Yan H and Liu RH: Comparative assessment of phenolic content and in vitro antioxidant capacity in the pulp and peel of mango cultivars. Int J Mol Sci 16: 13507-13527, 2015.

58. Hou N, Liu N, Han J, Yan Y and Li J: Chlorogenic acid induces reactive oxygen species generation and inhibits the viability of human colon cancer cells. Anticancer Drugs 28: 59-65, 2017.

59. Gao J, Yu H, Guo W, Kong Y, Gu L, Li Q, Yang S, Zhang Y and Wang Y: The anticancer effects of ferulic acid is associated with induction of cell cycle arrest and autophagy in cervical cancer cells. Cancer Cell Int 18: 102, 2018. 
60. Sun G, Zhang S, Xie Y, Zhang Z and Zhao W: Gallic acid as a selective anticancer agent that induces apoptosis in SMMC-7721 human hepatocellular carcinoma cells. Oncol Lett 11: 150-158, 2016.

61. Wang B, Shen J, Wang Z, Liu J, Ning Z and Hu M: Isomangiferin, a novel potent vascular endothelial growth factor receptor 2 kinase inhibitor, suppresses breast cancer growth, metastasis and angiogenesis. J Breast Cancer 21: 11-20, 2018.

62. Burmistrova O, Quintana J, Díaz JG and Estévez F: Astragalin heptaacetate-induced cell death in human leukemia cells is dependent on caspases and activates the MAPK pathway. Cancer Lett 309: 71-77, 2011.

63. Peng ZG, Yao YB, Yang J, Tang YL and Huang X: Mangiferin induces cell cycle arrest at G2/M phase through ATR-Chk1 pathway in HL-60 leukemia cells. Genet Mol Res 14: 4989-5002, 2015.

64. Peng ZG, Luo J, Xia LH, Chen Y and Song SJ: CML cell line K562 cell apoptosis induced by mangiferin. Zhongguo Shi Yan Xue Ye Xue Za Zhi 12: 590-594, 2004 (In Chinese).

65. Zou B, Wang H,Liu Y, Qi P, Lei T, Sun M and Wang Y: Mangiferin induces apoptosis in human ovarian adenocarcinoma OVCAR3 cells via the regulation of Notch3. Oncol Rep 38: 1431-1441, 2017.

66. Mohan CG, Deepak M, Viswanatha GL, Savinay G, Hanumantharaju V, Rajendra CE and Halemani PD: Anti-oxidant and anti-inflammatory activity of leaf extracts and fractions of Mangifera indica. Asian Pac J Trop Med 6: 311-314, 2013.

67. Shen X, Si Y, Wang Z, Wang J, Guo Y and Zhang X: Quercetin inhibits the growth of human gastric cancer stem cells by inducing mitochondrial-dependent apoptosis through the inhibition of PI3K/Akt signaling. Int J Mol Med 38: 619-626, 2016.

68. Srivastava S, Somasagara RR, Hegde M, Nishana M, Tadi SK, Srivastava M, Choudhary B and Raghavan SC: Quercetin, a natural flavonoid interacts with DNA, arrests cell cycle and causes tumor regression by activating mitochondrial pathway of apoptosis. Sci Rep 6: 24049, 2016.

69. Pardede A and Koketsu M: Antioxidant and antileukemic activity of chemical components from bark of Mangifera casturi. Comp Clin Path 26: 499-504, 2017.

70. Wang Y, Hong D, Qian Y, Tu X, Wang K, Yang X, Shao S, Kong $X$, Lou $Z$ and Jin L: Lupeol inhibits growth and migration in two human colorectal cancer cell lines by suppression of Wnt- $\beta$-catenin pathway. Onco Targets Ther 11: 7987-799, 2018.

71. Ahmad S, Sukari MA, Ismail N, Ismail IS, Abdul AB Abu Bakar MF, Kifli N and Ee GC: Phytochemicals from Mangifera pajang Kosterm and their biological activities. BMC Complement Altern Med 15: 83, 2015.

72. Razak S, Afsar T, Ullah A, Almajwal A, Alkholief M, Alshamsan A and Jahan S: Taxifolin, a natural flavonoid interacts with cell cycle regulators causes cell cycle arrest and causes tumor regression by activating Wnt/ $\beta$-catenin signaling pathway. BMC Cancer 18: 1043, 2018.

73. Ediriweera MK, Tennekoon KH, Samarakoon SR, Thabrew and De Silva ED: Cytotoxic and apoptotic effects of the bark of two common mango (Mangifera indica) varieties from Sri Lanka on breast and ovarian cancer cells. Br J Pharm Res 10: 1-7, 2016.

74. Ferhi S, Santaniello S, Zerizer S, Cruciani S, Fadda A, Sanna D, Dore A, Maioli M and D'hallewin G: Total phenols from grape leaves counteract cell proliferation and modulate apoptosis-related gene expression in MCF-7 and HepG2 human cancer cell lines. Molecules 24: 612, 2019.

75. Scarlatti F, Maffei R, Beau I, Codogno P and Ghidoni R: Role of non-canonical Beclin 1-independent autophagy in cell death induced by resveratrol in human breast cancer cells. Cell Death Differ 15: 1318-1329, 2008

76. Jo EH, Lee SJ, Ahn NS, Park JS, Hwang JW, Kim SH, Aruoma OI, Lee YS and Kang KS: Induction of apoptosis in MCF-7 and MDA-MB-231 breast cancer cells by Oligonol is mediated by Bcl-2 family regulation and MEK/ERK signaling. Eur J Cancer Prev 16: 342-347, 2007

77. Morré DM and Morré DJ: Anticancer activity of grape and grape skin extracts alone and combined with green tea infusions. Cancer Lett 238: 202-209, 2006.

78. Schuebel K, Gitik M, Domschke K and Goldman D: Making sense of epigenetics. Int J Neuropsychopharmacol 19: pyw058, 2016.

79. Szyf M and Meaney MJ: Epigenetics, behaviour, and health Allergy Asthma Clin Immunol 4: 37-49, 2008.

80. Hamilton JP: Epigenetics: Principles and practice. Dig Dis 29: $130-135,2011$
81. Rozek LS, Dolinoy DC, Sartor MA and Omenn GS: Epigenetics: Relevance and implications for public health. Annu Rev Public Health 35: 105-122, 2014.

82. Moosavi A and Motevalizadeh Ardekani A: Role of epigenetics in biology and human diseases. Iran Biomed J 20: 246-258, 2016

83. Margueron R and Reinberg D: Chromatin structure and the inheritance of epigenetic information. Nat Rev Genet 11 285-296, 2010

84. Jones PA and Laird PW: Cancer epigenetics comes of age. Nat Genet 21: 163-167, 1999

85. Jones PA and Baylin SB: The fundamental role of epigenetic events in cancer. Nat Rev Genet 3: 415-428, 2002.

86. Rauluseviciute I, Drabløs F and Rye MB: DNA hypermethylation associated with upregulated gene expression in prostate cancer demonstrates the diversity of epigenetic regulation. BMC Med Genomics 13: 6, 2020.

87. Liang TJ, Wang HX, Zheng YY, Cao YQ, Wu X, Zhou X and Dong SX: APC hypermethylation for early diagnosis of colorectal cancer: A meta-analysis and literature review. Oncotarget 8: 46468-46479, 2017

88. McLaughlin SK, Olsen SN, Dake B, De Raedt T, Lim E, Bronson RT, Beroukhim R, Polyak K, Brown M, Kuperwasser C and Cichowski K: The RasGAP gene, RASAL2, is a tumor and metastasis suppressor. Cancer Cell 24: 365-378, 2013

89. Williams BP, Pignatta D, Henikoff $S$ and Gehring $M$ Methylation-sensitive expression of a DNA demethylase gene serves as an epigenetic rheostat. PLoS Genet 11: e1005142, 2015.

90. Da Costa EM, McInnes G, Beaudry A and Raynal NJ: DNA methylation-targeted drugs. Cancer J 23: 270-276, 2017.

91. Christman JK: 5-Azacytidine and 5-aza-2'-deoxycytidine as inhibitors of DNA methylation: Mechanistic studies and their implications for cancer therapy. Oncogene 21: 5483-5495, 2002

92. Javaid $\mathrm{N}$ and Choi S: Acetylation- and methylation-related epigenetic proteins in the context of their targets. Genes (Basel) 8: 196, 2017.

93. Handy DE, Castro R and Loscalzo J: Epigenetic modifications: Basic mechanisms and role in cardiovascular disease Circulation 123: 2145-2156, 2011.

94. Eberharter A and Becker PB: Histone acetylation: A switch between repressive and permissive chromatin. Second in review series on chromatin dynamics. EMBO Rep 3: 224-229, 2002.

95. Ropero $\mathrm{S}$ and Esteller M: The role of histone deacetylases (HDACs) in human cancer. Mol Oncol 1: 19-25, 2007.

96. Shanmugam MK, Arfuso F, Arumugam S, Chinnathambi A, Jinsong B, Warrier S, Wang LZ, Kumar AP, Ahn KS, Sethi G and Lakshmanan M: Role of novel histone modifications in cancer. Oncotarget 9: 11414-11426, 2018

97. Ju R and Muller MT: Histone deacetylase inhibitors activate p21(WAF1) expression via ATM. Cancer Res 63: 2891-2897, 2003.

98. Shamloo U and Usluer S: p21 in cancer research. Cancers (Basel) 11: 1178, 2019.

99. Ediriweera MK and Cho SK: Targeting miRNAs by histone deacetylase inhibitors (HDACi): Rationalizing epigenetics-based therapies for breast cancer. Pharmacol Ther 206: 107437, 2020.

100. Suraweera A, O'Byrne KJ and Richard DJ: Combination therapy with histone deacetylase inhibitors (HDACi) for the treatmen of cancer: Achieving the full therapeutic potential of HDACi. Front Oncol 8: 92, 2018.

101. Lau PW and MacRae IJ: The molecular machines that mediate microRNA maturation. J Cell Mol Med 13: 54-60, 2008

102. Wei JW, Huang K, Yang C and Kang CS: Non-coding RNAs as regulators in epigenetics. Oncol Rep 37: 3-9, 2017.

103. Moutinho $\mathrm{C}$ and Esteller M: MicroRNAs and epigenetics. Adv Cancer Res 135: 189-220, 2017.

104. Mazzio EA, Soliman KFA: HTP Nutraceutical screening for histone deacetylase inhibitors and effects of HDACis on Tumor-suppressing miRNAs by Trichostatin A and Grapeseed (Vitis vinifera) in HeLa cells. Cancer Genomics Proteomics 14 17-34, 2017.

105. Nguyen DD and Chang S: Development of novel therapeutic agents by inhibition of oncogenic MicroRNAs. Int J Mol Sci 19: 65, 2017.

106. Peng Y and Croce CM: The role of MicroRNAs in human cancer. Signal Transduct Target Ther 1: 15004, 2016.

107. Krutovskikh VA and Herceg Z: Oncogenic microRNAs (OncomiRs) as a new class of cancer biomarkers. Bioessays 32 894-904, 2010.

108. Ciesielski O, Biesiekierska $M$ and Balcerczyk A: Epigallocatechin-3-gallate (EGCG) alters histone acetylation and methylation and impacts chromatin architecture profile in human endothelial cells. Molecules 25: 2326, 2020. 
109. Zhou H, Chen JX, Yang CS, Yang MQ, Deng Y and Wang H: Gene regulation mediated by microRNAs in response to green tea polyphenol EGCG in mouse lung cancer. BMC Genomics 15 (Suppl 11): S3, 2014.

110. Ma Y, Liu Y, Ma Y, Jiang N, Wang L, Wang B, Niu W, Hu Y, Lin Q and Yu B: Mangiferin relieves lipopolysaccharide-induced injury by up-regulating miR-181a via targeting PTEN in ATDC5 cells. Front Pharmacol 11: 137, 2020.

111. Xiao J, Liu LI, Zhong Z, Xiao C and Zhang J: Mangiferin regulates proliferation and apoptosis in glioma cells by induction of microRNA-15b and inhibition of MMP-9 expression. Oncol Rep 33: 2815-2820, 2015.

112. Alberdi E, Sánchez-Gómez MV, Ruiz A, Cavaliere F Ortiz-Sanz C, Quintela-López T, Capetillo-Zarate E, Solé-Domènech S and Matute C: Mangiferin and Morin attenuate oxidative stress, mitochondrial dysfunction, and neurocytotoxicity, induced by amyloid beta oligomers. Oxid Med Cell Longev 2018: 2856063, 2018

113. Lemus-Molina Y, Sánchez-Gómez MV, Delgado-Hernández R and Matute C: Mangifera indica L. extract attenuates glutamate-induced neurotoxicity on rat cortical neurons. Neurotoxicology 30: 1053-1058, 2009.

114. Ajila CM, Rao LJ and Rao UJ: Characterization of bioactive compounds from raw and ripe Mangifera indica L. peel extracts. Food Chem Toxicol 48: 3406-3411, 2010.

115. Muruganandan S, Gupta S, Kataria M, Lal J and Gupta PK: Mangiferin protects the streptozotocin-induced oxidative damage to cardiac and renal tissues in rats. Toxicology 176 165-173, 2002.

116. Rajendran P, Ekambaram G and Sakthisekaran D: Effect of mangiferin on benzo(a)pyrene induced lung carcinogenesis in experimental Swiss albino mice. Nat Prod Res 22: 672-680, 2008.
117. Wang RR, Gao YD, Ma CH, Zhang XJ, Huang CG, Huang JF and Zheng YT: Mangiferin, an anti-HIV-1 agent targeting protease and effective against resistant strains. Molecules 16: 4264-4277, 2011.

118. Takeda T, Tsubaki M, Kino T, Yamagishi M, Iida M, Itoh T, Imano M, Tanabe G, Muraoka O, Satou T and Nishida S: Mangiferin induces apoptosis in multiple myeloma cell lines by suppressing the activation of nuclear factor kappa B-inducing kinase. Chem Biol Interact 251: 26-33, 2016.

119. Biersack B: Current state of phenolic and terpenoidal dietary factors and natural products as non-coding RNA/microRNA modulators for improved cancer therapy and prevention. Noncoding RNA Res 1: 12-34, 2016.

120. Paolini A, Curti V, Pasi F, Mazzini G, Nano R and Capelli E: Gallic acid exerts a protective or an anti-proliferative effect on glioma T98G cells via dose-dependent epigenetic regulation mediated by miRNAs. Int J Oncol 46: 1491-1497, 2015.

121. Sundaram KM, Hussain A, Haque S, Raina R and Afroze N: Quercetin modifies $5^{\prime} \mathrm{CpG}$ promoter methylation and reactivates various tumor suppressor genes by modulating epigenetic marks in human cervical cancer cells. J Cell Biochem 120: 18357-18369, 2019.

122. Bishayee K, Khuda-Bukhsh AR and Huh SO: PLGA-loaded Gold-nanoparticles precipitated with quercetin downregulate HDAC-Akt activities controlling proliferation and activate p53-ROS crosstalk to induce apoptosis in hepatocarcinoma cells. Mol Cells 38: 518-527, 2015.

(i) $\Theta$ This work is licensed under a Creative Commons Attribution-NonCommercial-NoDerivatives 4.0 International (CC BY-NC-ND 4.0) License. 